\title{
Formulasi Micellar Based Water Ekstrak Bunga Telang
}

\author{
Muhammad Dzakwan*1 \\ ${ }^{1}$ Fakultas Farmasi Universitas Setia Budi Surakarta \\ Jln. Let. Jend. Sutoyo Mojosongo Jebres Surakarta 57127 \\ e-mail: *1 mdzakwan9@setiabudi.ac.id
}

\section{Article Info}

Article history:

Submission Mei 2020

Accepted Juni 2020

Publish Juli 2020

\begin{abstract}
Abstrak
Bunga telang adalah bunga dari tanaman Clitoria ternatea dikenal sebagai bunga kupu-kupu. Memiliki beragam aktivitas farmakologi sebagai antioksidan, antikanker dan antidepresan. Ekstrak bunga telang banyak digunakan dalam bidang kosmetik dan obat. Micellar based water adalah produk kosmetik yang berfungsi untuk membersihkan wajah atau make up dan mengunakan air sebagai pelarut utama. Tujuan penelitian adalah formulasi dan mengembangkan sediaan micellar dengan variasi konsentrasi polimer amfifil. Hasil penelitian menunjukan, formula 5 dengan konsentrasi polimer amfifil $1 \%$ adalah formula paling stabil dengan tampilan fisik jernih, tidak terjadi pengendapan, memiliki ukuran partikel 46,67 $\mathrm{nm}$ dan potensial zeta 28,4 mV. Kesimpulan, ekstrak bunga telang berhasil diformulasi menjadi sediaan micellar based water dengan aktivitas antioksidan $\left(I_{50}\right) 1,30 \mathrm{mg} / \mathrm{ml}$ setara dengan ekstrak murni
\end{abstract}

Kata kunci-Bunga telang, Ekstrak Micellar based water Polimer amfifil Antioksidan
Ucapan Terima kasih diberikan kepada Fakultas Farmasi Universitas Setia Budi dan Tim Laboran yang telah membantu kelancaran penelitian ini

\begin{abstract}
Clitoria ternatea is a twining herbal medicinal plant. It has pharmacological activity as antioxidant, anticancer and anti depressant. Extracts of $C$ ternatea flowers were used as a component of cosmetics. The aim of this research is to formulate and develop micellar based water with variation concentration of amphiphilic polymer. Results showed that formulation containing amphiphilic polymer $1 \%(F 5)$ is the most stable, clearly, particle size distribution of 46,67 $\mathrm{nm}$ and zeta potential $-18,4 \mathrm{mV}$ was obtained. Conclution, extracts of $\mathrm{C}$ ternatea flowers successfully formulaed to micellar based water, antioxidant activity $\left(I C_{50}\right)$ of $1,30 \mathrm{mg} / \mathrm{ml}$ was obtained.
\end{abstract}

Keyword - C ternatea of flower Extract Micellar Based Water Amphiphilic polymer Antioxidant 


\section{A. Pendahuluan}

Micellar adalah kumpulan molekul polimer amfifilik, blok kopolimer atau surfaktan yang memiliki ukuran nanometer $(10-100 \mathrm{~nm})$. Micellar memiliki bagian inti (core) bersifat hidrofobik dan cangkang (shell) bersifat hidrofilik, yang terdispersi dalam sistem larutan homogen ${ }^{[1][2][3]}$. Micellar yang berasal dari polimer amfifil atau blok kopolimer lebih mudah terbentuk dengan konsentrasi yang sangat rendah, dibandingkan micellar dari surfaktan ${ }^{[1]}$.

Micellar memiiki kemampuan melarutkan, stabilisasi dan membersihkan kotoran yang bersifat lipofil seperti lemak dan minyak sehingga banyak digunakan dalam sediaan kosmetik [4][5]. Mekanisme kerja micellar dalam membersihkan kotoran seperti spons dengan menghidrasi kulit wajah dan melarutkan kotoran sehingga mudah dibersihkan ${ }^{[6]}$.

Micellar based water adalah produk kosmetik yang dibuat untuk membersihkan wajah atau make up, dengan komponen adalah air. Selain mengandung bahan pelembab seringkali micellar based water dikombinasi dengan antioksidan dan pencerah kulit ${ }^{[7]}$. Keuntungan penggunaan micellar based water adalah tidak mengiritasi kulit saat digunakan dan digunakan untuk semua jenis kulit ${ }^{[8]}$.

Banyak tipe polimer amfifil yang digunakan sebagai micellar agents salah satunya adalah golongan poloksamer atau pluronik [9]. Poloksamer terdiri beberapa tipe diantaranya poloksamer L61, P85, F127 dan poloksamer F68 [10]. Salah satu jenis poloksamer yang banyak digunakan dalam kosmetik sebagai pembentuk misel adalah poloksamer F68 [11]. Poloksamer F68 memiliki beberapa keuntungan yaitu konsentrasi misel kritis yang sangat rendah sehingga potensi toksisitas minimal, tidak mengiritasi, mudah larut dalam air, kemampuan solubilisasi yang tinggi, stabil secara termodinamika di dalam larutan, memiliki efek hidrasi dan pembersihan terhadap kotoran baik yang bersifat lipofil maupun hidrofil [11][12][13].

Salah satu tanaman yang dikenal memiliki manfaat untuk kesehatan dan banyak digunakan dalam kosmetik adalah telang (Clitoria ternatea) ${ }^{[14]}$. Telang memiliki khasiat sebagai antioksidant, antiinflamasi, antikanker dan menurunkan kadar lipid dalam darah [15][16]. Bagian tanaman telang yang digunakan untuk pengobatan dan kaya akan kandungan zat aktif adalah bunga, yang berwarna ungu hingga biru ${ }^{[17]}$. Bunga telang mengandung senyawa antosianin, kaemferol, kuersetin, mirisetin, taksasaerol, malvidin-3 $\beta$ glukosida dan $\beta$ sitosterol [18][19]. Aktivitas antioksidan ekstrak bunga telang yang tinggi berkaitan langsung dengan kadar senyawa fenolik terutama antosianin. Menurut ${ }^{[20]} \mathrm{kadar}$ total antosianain yang terkandung dalam ekstrak bunga telang sebesar $16.07 \mathrm{mg} / \mathrm{g}$ bahan dan bertangung jawab terhadap aktivitas antioksidan serta aktifitas farmakologi sebagai antikanker, antitumor dan penyakit neurodegenerative.

Hasil penelitian [21] menunjukan bahwa ekstrak air bunga telang memiliki aktivitas antioksidan yang lebih kuat sebesar $1 \mathrm{mg} / \mathrm{ml}$ dibandingkan dengan ekstrak etanol sebesar 4 $\mathrm{mg} / \mathrm{ml}$. Ekstrak etanol bunga telang dengan dosis $250 \mathrm{mg} / \mathrm{KgBB}$ terbukti memiliki aktivitas nefroprotektif dengan dosis ${ }^{[17]}$. Di beberapa negara seperti Thailand ekstrak bunga telang digunakan dalam beberapa produk kosmetik sebagai antipenuaan dini, antioskidan. tonik wajah dan pencerah kulit [22].
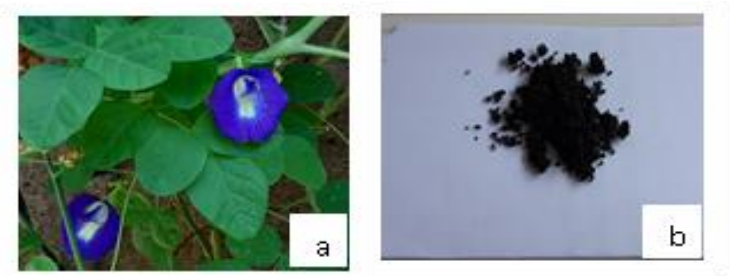

Gambar 1. Bunga telang (Clitoria ternatea)

(a) dan ekstrak kering bunga telang (b)

Tujuan dari penelitian ini adalah membuat formula dan sediaan micellar larut air dari ekstrak bunga telang dengan variasi konsentrasi polimer amfifil. Karakterisasi micellar meliputi tampilan fisik, ukuran partikel, indeks polidispersitas, zeta potensial, stabilitas selama penyimpanan pada suhu ruang dan aktivitas antioksidan.

\section{B. Metode}

\section{Alat}

Alat yang digunakan dalam penelitian ini adalah spektrofotometri UV-Vis (Shimadzu 1800, Jepang), analisis ukuran partikel dan zeta potensial (Malvern Zeta Sizer ZS 200, UK). Pengaduk magnetik (Thermo Scientific, Cina). Mikro pipet dengan berbagai volume (Socorex Acura 825, Swiss). Semua alat gelas 
sesuai spesifikasinya.

\section{Bahan}

Bahan yang digunakan dalam penelitian ini adalah ekstrak kering bunga telang (98\%, Greenherb Biological Technology Co. Ltd, China), Poloksamer F86 (PT. Mega Setia, Jakarta), pentilen glikol dan fenoksietanol SA (PT. Cortico Mulia Sejahtera, Jakarta ), gliserin, asam laktat dan natrium glukonat (CV. Cipta Kimia, Surakarta). Aquabidest (PT. Ikaphamindo, Jakarta).

\section{Jalanya Penelitian}

\section{Formulasi micellar based water}

Tahap awal penelitian ini adalah merancang formula micellar dengan komposisi utama yaitu ekstrak bunga telang sebagai bahan aktif, polimer amfifil, humektan, penstabil dan pelarut. Sedangkan bahan tambahan lainya adalah pengawet dan pengaroma. Formula micellar tersaji pada tabel 1.

Tabel 1. Formula micellar based water ekstrak bunga telang

\begin{tabular}{|c|c|c|c|c|c|}
\hline \multirow{2}{*}{ Bahan } & \multicolumn{5}{|c|}{ Formula (\%) } \\
\hline & F1 & F2 & F3 & F4 & F5 \\
\hline $\begin{array}{l}\text { Ekstrak bunga } \\
\text { telang }\end{array}$ & 1 & 1 & 1 & 1 & 1 \\
\hline Poloksamer F68 & 0,2 & 0,4 & 0,6 & 0,8 & 1 \\
\hline Natrium glukonat & 0,2 & 0,2 & 0,2 & 0,2 & 0,2 \\
\hline Pentilen glikol & 1,5 & 1,5 & 1,5 & 1,5 & 1,5 \\
\hline Gliserin & 0,25 & 0,25 & 0,25 & 0,25 & 0,25 \\
\hline Fenoksietanol SA & 0,2 & 0,2 & 0,2 & 0,2 & 0,2 \\
\hline Asam laktat & q.s & q.s & q.s & q.s & q.s \\
\hline Aquadest & 96,6 & 94,4 & 96,2 & 96,0 & 95,8 \\
\hline & 5 & 5 & 5 & 5 & 5 \\
\hline Volume sediaan & & & 50 & & \\
\hline
\end{tabular}

2. Karakterisasi fisik micellar

Sediaan micellar di karakterisasi meliputi tampilan fisik, tingkat kejernihan, $\mathrm{pH}$ dan viskositas.

\section{Ukuran partikel dan zeta potensial}

Distribusi ukuran partikel, indeks polidispersitas dan potensial zeta di tentukan dengan menggunakan alat Zetasizer Nano ZS (Malvern Instrument UK)

\section{Uji stabilitas}

Sediaan micellar disimpan pada suhu ruang selama 8 minggu sambil diamati adanya perubahan fisik seperti kejernihan, pengendapan dan pemisahan fase. Sediana yang paling stabil digunakan untuk uji aktivitas antioksidan.

\section{Uji aktivitas antoksidan}

Uji aktivitas antioksidan ekstrak kering bunga telang dan sediaan micellar dengan metode DPPH

\section{Hasil Dan Pembahasan}

\section{Formulasi dan pembuatan micellar}

Pembuatan micellar menggunakan metode pelarutan melalui proses pengadukan dengan magnetik stirrer, hal ini bertujuan untuk mempercepat malarutnya komponen atau bahan micellar. Poloksamer F68 merupakan amfifil hidrofil yang sangat mudah larut dalam aquadest. Ekstrak bunga telang bersifat hidrofil sehingga sangat mudah larut di dalam air dan tidak memerlukan bahan peningkat kelarutan.

Gliserin dan pentilen glikol berfungsi sebagai humektan untuk mencegah dehidrasi kulit. Untuk meningkatkan stabilitas sediaan maka ditambahkan natrium glikolat, yang bekerja dengan meningkatkan afinitas antara polimer amfifil dengan bahan aktif. Penggunaan natrium glikolat biasanya akan meningkatkan nilai $\mathrm{pH}$ sediaan sampai mencapai $\mathrm{pH}$ basa oleh karena itu ditambahkan asam laktat untuk menetralkan pH. Asam laktat banyak digunakan dalam sediaan micellar karena bersifat nontoksik, tidak mengiritasi dana aman [12]. Sediaan micellar ekstrak bunga telang dapat dilihat pada gambar 2 di bawah ini.

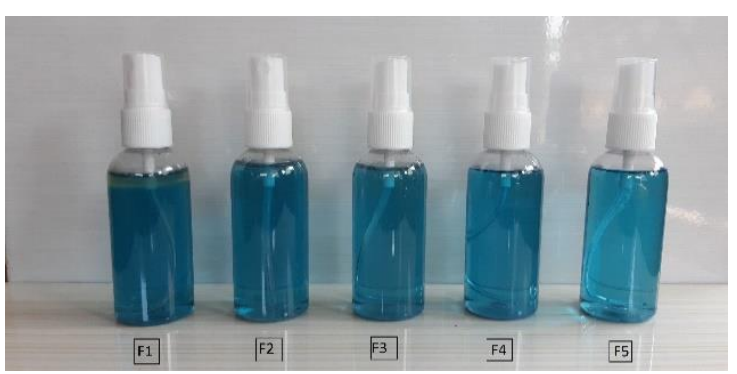

Gambar 2. Sediaan micellar ekstrak bunga elang berwarna biru alami F1-F5 
Fenoksietanol SA merupakan pengawet yang bukan golongan EDC (Endocrine Discruption Chemicals) yang tidak menyebabkan kerusakan kelenjar endokrin sehinga aman digunakan sebagai pengawet pada sediaan micellar ${ }^{[23]}$. Semua sediaan micellar berwarna biru muda yang disebakan oleh senyawa antosianin yang terkandung dalam ekstrak bunga telang. Formula 1, 2 dan 3 dengan konsentrasi poloksamer F68 masing-masing $0,2 \% ; 0,4 \%$ dan $0,6 \%$ terlihat keruh, terjadi pengendapan dan pemisahan fase. Menurut ${ }^{[24]}$ hal ini disebabkan pada konsentrasi 0,2-0,6\% kemungkinan molekul amfifil belum membentuk misel karena konsentrasi masih rendah sehingga kemampuan untuk melarutkan zat lebih kecil dan cenderung akan terjadi pengendapan. Formula 4 dengan konsentrasi poloksamer F68 0,8\% terlihat lebih jernih dibandingkan dengan $\mathrm{F} 1$, tidak terjadi pemisahan fase akan tetapi masih terjadi pengendapan partikel, hal ini kemungkinan pada konsentrasi tersebut sudah mulai terbentuk misel tetapi belum sampai mencapi konsentrasi kritisnya sehingga kemampuan melarutakn zat belum maksimal ${ }^{[25]}$. Formula 5 dengan konsentrasi poloksamer F68 1\% terlihat paling jernih jika dibandingkan dengan formula lainya, tidak terjadi pemisahan fase dan pengendapan zat hal ini disebabkan pada konsentrasi tersebut sudah tercapai konsentrasi misel kritis sehingga misel akan terbentuk lebih maksimal, kemampuan melarutkan zat lebih besar dan zat aktif akan terlarut sempurna ${ }^{[26]}$.

Poloksamer F68 ketika terlarut secara spontan akan membentuk 2 bagian yaitu inti hidrofobik dan corona hidrofilik. Inti hidrofobik akan melarutkan zat yang bersifat hidrofob sedangkan corona hidrofilik akan berinteraksi dan melarutkan zat hidrofilik, Poloksamer F68 memiliki rantai hidrofilik yang cukup besar sehingga memiliki kemampuan melarutkan zat yang bersifat hidrofilik dalam jumlah yang besar pula ${ }^{[1]}$. Ekstrak bunga telang bersifat larut air atau hidrofil maka akan masuk ke dalam corona hidrofilik kemudian melarut secara maksimal.

\section{Karakterisasi fisik dan ukuran partikel micellar}

Hasil karakterisasi fisik menunjukan F1 F3, sedian tampak keruh dan terjadi pengendapan partikel, sedangkan F4 dan F5 lebih jernih. Hasil pengukuran $\mathrm{pH}$ menunjukan semua formula sediaan memiliki $\mathrm{pH}$ netral yaitu antara 6,8-7,0. Hal ini sesuai dengan persyaratan untuk sediaan kosmetik terutama sediaan pembersih wajah harus netral dengan rentang $\mathrm{pH}$ antara $6,8-7,2$ [27]. Micellar based water merupakan sistem larutan yang homogen dengan konsistensi encer, hasil pengukuran viskositas semua formula memiliki kekentalan rata-rata sebesar 20 cps. Hasil pengukuran ukuran partikel sediaan micellar tersaji pada tabel 2 dibawah ini.

Tabel 2. Hasil pengukuran ukuran partikel

\begin{tabular}{ccc}
\multicolumn{3}{c}{ micellar } \\
\hline Formula & $\mathbf{Z}_{\text {average (nm) }}$ & PI \\
F 1 & 1364,10 & 0,404 \\
F 2 & 1120,15 & 0,377 \\
F 3 & 252,20 & 0,280 \\
F 4 & 105,30 & 0,205 \\
F 5 & 41,64 & 0,280
\end{tabular}

Formula 1 dan 2 memiliki ukuran partikel lebih besar dari $1000 \mathrm{~nm}(1 \mu \mathrm{m})$ hal ini disebabkan terjadi agregasi dan pengendapan partikel sebagai akibat misel belum terbentuk sehingga kemampuan melarutkan zat aktif sangat kecil dan partikel cenderung akan mengendap. Formula 3 memiliki ukuran partikel lebih kecil dari F1 dan F2 akan tetapi masih lebih besar dari $100 \mathrm{~nm}$. Formula 4 dan 5 memiliki ukuran partikel lebih kecil dari formula yang lainya yaitu sebesar 105,30 nm dan 41,64 nm, hal ini sudah masuk dalam rentang ukuran misel yaitu $10-100 \mathrm{~nm}$. Formula 4 dan 5 selanjutnya digunakan untuk pengujian stabilitas penyimpanan pada suhu kamar.

Hasil uji stabilitas ditampilkan pada gambar 3 di bawah ini.
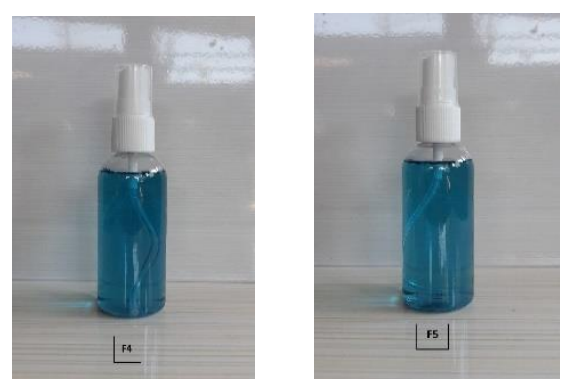

Gambar 3. Hasil uji stabilitas micellar F4 dan F5. F4 nampak lebih keruh dan F5 tetap jernih.

Hasil uji stabilitas menunjukan formula 5 dengan konsentrasi poloksamer F68 1\% lebih 
stabil dibandingkan dengan formula 4 , terlihat jernih, tidak mengalami agregasi dan pengendapan partikel. Hasil pengujian ukuran partikel dan potensial zeta ditampilkan pada tabel 3 dan gambar 4 dan 5 .

Tabel 3. Hasil pengukuran stabilitas ukuran

\begin{tabular}{cccc}
\hline Formula & $\mathbf{Z}_{\text {average }(\mathbf{n m})}$ & PI & $\zeta_{(\mathbf{m V})}$ \\
F 4 & 540,10 & 0,315 & $-10,12$ \\
F 5 & 46,67 & 0,281 & $-28,4$ \\
& & & \\
\hline
\end{tabular}

Hasil pengujian ukuran partikel menunjukan formula 4 terjadi agregasi sehingga ukuran partikel menjadi lebih besar jika dibandingakn sebelum pengujian yaitu sebesar $540,10 \mathrm{~nm}$, sedangkan ukuran partikel formula 5 tidak terjadi agregrasi dan ukuran partikel relatif stabil sebesar 46,67 nm dengan potensial zeta sebesar $-28,4 \mathrm{mV}$. Formula 5 selanjutnya digunakan untuk uji aktivitas antioksidan partikel/

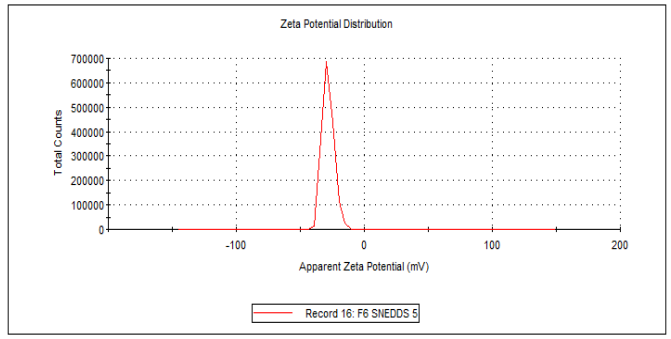

Gambar 4. Distribusi ukuran partikel micellar F5

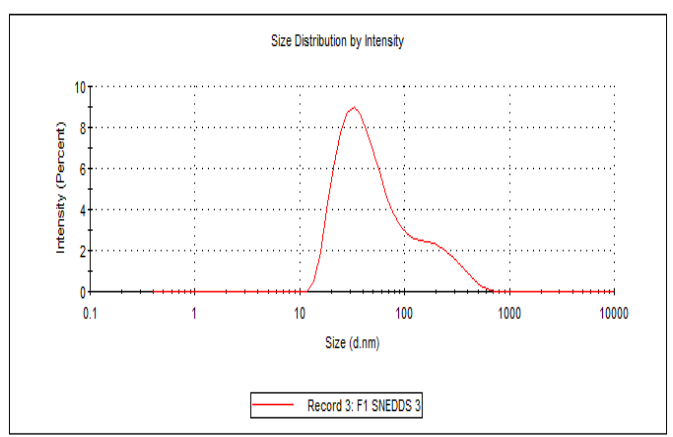

Gambar 5. Zeta potensial micellar F5

\section{Uji aktivitas antioksidan micellar based water}

Hasil pengujian aktivitas antioksidan sediaan micellar based water dan ekstrak murni bunga telang ditampilkan pada tabel 4 dibawah ini.
Tabel 4. Hasil uji aktivitas antioksidan

$\begin{array}{ccc}\text { Formula } & \mathbf{I C}_{\mathbf{5 0} \mathbf{u j i}} & \mathbf{I C}_{\mathbf{5 0} \text { referensi }} \\ \mathbf{F 5} & 1,30 \mathrm{mg} / \mathrm{ml} & - \\ \text { Ekstrak } & 1,2 \mathrm{mg} / \mathrm{ml} & 1-4 \mathrm{mg} / \mathrm{ml}\end{array}$

Sediaan micellar based water masih menunjukan aktivitas antioksidan yang poten setara dengan aktivitas antioksidan ekstrak murni, hasil ini selaras dengan $\mathrm{IC}_{50}$ aktivitas antioksidan hasil pengujian yang dilakukan oleh Kamkaen and Wilkinson (2009) sebesar 1-4 $\mathrm{mg} / \mathrm{ml}$. Aktivitas antioksidan sediaan micellar kemungkinan disebabkan oleh kandungan senyawa polifenol seperti antosianin dan flavonoid yang terkandung di dalam ekstrak bunga telang. Menurut Chakraborthy et al (2018) kandungan terbesar bunga telang adalah antosianin dan flavonoid yang memiliki aktivitas antioksidan kuat.

\section{Simpulan}

Kesimpulan penelitian ini adalah ekstrak bunga telang telah berhasil dikembangkan menjadi sediaan micellar based water. Formula 5 dengan konsentrasi polimer amfifil $1 \%$ adalah formula palimg stabil dengan tampilan fisik jernih, tidak terjadi pengendapan, memiliki ukuran partikel 46,67 $\mathrm{nm}$ dan potensial zeta $-28,4 \mathrm{mV}$. Sediaan micellar based water memiliki aktivitas antioksidan dengan IC50 $1,30 \mathrm{mg} / \mathrm{ml}$ setara dengan ekstrak murni.

\section{Pustaka}

[1] .Douroumis D and Fahr A.,2013. Drug Delivery Strategies for Poorly WaterSoluble Drugs, Ed $1^{\text {st }}$, A John Wiley \& Sons, Ltd., United Kingdom, 411-430.

[2] Bansal M and Jamil S., 2018. Micellar Microparticles: A Novel Approach to Topical Drug Delivery System. Int J App Pharm, 10(5):1-5.

[3] Makhmalzade B S and Chavoshy F., 2019. Polymeric Micelles as Cutaneous Drug Delivery System in Normal Skin and Dermatological Disorders, Journal of Advanced Pharmaceutical Technology and Research, 9(1): 2-8.

[4] Miyata K, Christie J and Kataoka K., 2011. Polymeric Micelles for NanoScale Drug Delivery, Reactive and 
Functional Polymers, 71:227-234.

[5] Patil A and Ferritto M S., 2014. Polymers for Personal Care and Cosmetics: Overview, ACS Symposium Series; American Chemical Society: Washington DC, 3-10.

[6] Deshmukh A S, Chauhan P N, Noolvi M $\mathrm{N}$, Chaturvedi K, Ganguly $\mathrm{K}$ and Shukla S S., 2017. Polymeric Micelles: Basic Research to Clinical Practice. Int $J$ Pharm, 532: 249-268.

[7] Oliveira B P P and Rodrigues F., 2018. Plant Extracts in Skin Care Products, MDPI St. Alban-Anlage 66 Basel, Switzerland, 34-40.

[8] Jindal N. Mehta S K., 2015. Nevirapine Loaded Poloxamer 407/Pluronic P123 Mixed Micelles: Optimization of Formulation and In Vitro Evaluation. Colloids Surf. B Biointerfaces, 129: 100-106.

[9] Ricardo N M P S, Ricardo N M P S, Costa F de M L L, Bezzera F W A, Chaibundit C, Merino D H, Greenland B W, Burattini S, Hamley I W, Nixon S K and Yeates S G., 2012. Effect of Water Soluble polymers, Polyethylene Glicol and Poly(Vinylpyrrolidone), on the Gelation of Aqueous Micellar Solutions of Pluronic Copolymer F127, Journal of Colloid and Interface Science, 368: 336341.

[10] Oliveira C P, Vasconcellos L C G, Ribeiro M E N P, Ricardo N M P S, Souza T V de P, Costa F de M L L, Chaibundit C and Yeates S G., 2011. The Effect of Polymeric Additives on the Solubilisation of Poorly Soluble Drug in Micellar Solutions of Pluronic F127, International of Journal Pharmaceutics, 409:206-208.

[11] Samith V D, Mino G, Moore E R, Miranda N A., 2013. Effects of Pluronic F68 Micellization on The Viability of Neuronal Cells in Culture, J. Appl. Polym. Sci, 130(4): 2159-2164.

[12] Tadros T F., 2015. Viscoelastic Properties of Sterically Stabilized Emulsiona and Their Stability. Adv. Colloid Interface Sci, 222: 692-708.

[13] Bodratti A M and Alexandridis P., 2018. Formulation of Poloxamers for Drug
Delivery, Journal of Functional Biomaterials, 9(11): 2-24.

[14] Jadhav V, Deshmukh S and Mahadkar S.,2013. Evaluation of Antioxidant Potential of Clitoria Ternatea L, International Journal of Pharmacy and Pharmaceutical Sciences, 5(2): 595-599.

[15] Nanasombat $S$, Thonglong $J$ and Jitlakha J., 2015. Formulation and Characterization of Novel Functional Beverages with Antioxidant and AntiAcetylcholinesterase Activities, Functional Foods in Health and Disease, 5(1):1-16.

[16] Al-Snafi A S., 2016. Pharmacological importance of Clitoria ternatea - A review, IOSR Journal Of Pharmacy, 6(3): 68-83.

[17] Sarumathy K, Dhana Rajan M S, Vijay $\mathrm{T}$ and Jayakanthi J., 2011. Evaluation of Phytoconstituents, Nephro-Protective and Antioxidant Activities of Clitoria ternatea, Journal of Applied Pharmaceutical Science, 01 (05): 164172.

[18] Lijon M B, Meghla N S, Jahedi E, Abdur Rahman M and Hossain I., 2017. Phytochemistry and Pharmacological Activities of Clitoria ternatea, International Journal of Natural and Social Sciences, 43(1):01-10.

[19] Chakraborthy G S, Kumar V, Gupta S, Kumar A, Gautam N and Kumari L., 2018. Phytochemical and Pharmacological Aspects of Clitoria Ternatea- A Review, JAPSR, 1(2): 0309.

[20] Siti Azima A M, Noriham A and Manshoor N., 2014. Anthocyanin Content In Relation to The Antioxidant Activity and Colour Properties of Garcinia Mangostana Peel, Syzigium Cumini and Clitoria Ternatea Extracts, International Food Research Journal, 21(6): 2369-2375.

[21] Kamkaen N and Wilkinson J M., 2009. The Antioxidant Activity of Clitoria ternatea Flower Petal Extracts, and Eye Gel, Phytotherapy Research, 23: 16241625.

[22] Gupta G K, Chahal J and Bhatia M.,2010. Clitoria ternatea (L.): Old and 
New Aspects, Journal of Pharmacy

Research, 3(11) : 2610-2614.

[23] Yang O, Kim H L and Seo R K., 2015. Endocrine-Disrupting Chemicals: Review of Toxicological Mechanisms Using Molecular Pathway Analysis, $J$. Cance Prevention, 20(1): 12-24.

[24] Lu Y and Park K., 2013. Polymeric Micelles and Alternative Nanonized Delivery Vehicles for Poorly Soluble Drugs, Int J Pharm, 453:198-214.

[25] Seedhler N and Kanojia M., 2008. Micellar Solubilization of Some Poorly Soluble Antidiabetic Drugs: A Technical Note, AAPS PharmSciTech, 9(2): 43143.

[26] Tzankova V, Aluani D, Yordanov Y, Burdina M K, Petrov P, Bankova V, Simeonova R, Vitcheva V, Odjakov F, Apostolov A, Tzankov B and Yonccheva K., 2018. Micellar Porpolis Nanoformulation of High Antioxidant and Hepatoprotective Activity, Brazilian Journal of Pharmacognosi.

[27] Baki G and Alexander K S., 2015. Introduction to Cosmetic Formulation and Technology, Ed 1st, John Wiley \& Sons Inc, New Jersey, 15-45. 